\author{
УДК 338.467, 65.011.4 \\ JEL E32, G14, H54, L25 \\ DOI https://doi.org/10.17721/tppe.2019.39.7
}

Kuznetsova Mariya, assistant lecturer

Ponomarenko Serhii, Master's student

Taras Shevchenko National University of Kyiv

\title{
SUSTAINABLE DEVELOPMENT OF LEADING ELECTRICITY GENERATION COMPANIES IN UKRAINE: NON-FINANCIAL ASPECTS
}

This paper deals with the issue of sustainable development and integrated reporting following the most recent guidelines for energy generation companies in Ukraine. In the course of the study, key performance peculiarities of leading electricity generation companies were revealed in the context of compliance with international requirements and global challenges. Main factors of the Ukrainian energy sector development prospects were identified in order to find out several opportunities for future growth and structural shifts.

The theoretical base and practical background were indicated following the already established standards and widespread principles as well as mechanisms for corporate performance management and integrated reporting release. The most substantial features of various electricity generation types were outlined in scope of national sectoral prerequisites. On the basis of data given in annual corporate reports as well as statistical data the comparative analysis of various non-financial initiatives and corporate social responsibility projects was held to reveal the most crucial differences in performance coverage and result improvement. The significance of social and ecological programs were proved in terms of sustainable development and high efficiency, taking into account both internal and external functional aspects.

Key words: business performance management, corporate social responsibility, electricity generation, integrated reporting, sustainable development, sustainability.

Problem description. Globalization issue has proven its broad impact on every sphere of human life. The foreseen tendencies of future development demonstrate an increasing pressure on corporations in terms of conscious, transparent and responsible performance following the international guidelines and reporting standards. Sustainable development policies and corporate social responsibility practices have already become the integral part of every major company in various sectors of economy, including electricity generation one. Following the irreversible climate changes and great performance risks, specific programs and broad policies are needed in order to meet social expectations and global demands as well as establish new practical tools for non-financial aspects coverage and efficient reporting in general.

Analysis of recent publications. Recent research studies on sustainability issues have already proven the validity and undoubted necessity to thoroughly investigate both financial and non-financial aspects of corporate performance in order to reach high level of customers' loyalty and public awareness. Some practical imperatives regarding sustainable development of crucial industries were revealed in study by Kukharuk $A$. and Zmitrovych D. [1], Khalatov A. [2] focused research interest on energy sector in Ukraine in terms of its potential fulfillment and strategic growth, whereas Vasylchuk I. [3] outlined the 
importance of sustainability reporting for modern corporations. Several essential directions of future development of electricity generation were demonstrated in research by Owusu P. and Asumadu-Sarkodie S. [4], whereas Urban F. and Mitchell T. [5] showed the importance of considering climate change risks and disasters prevention.

Outstanding issues. New business approaches and management concepts set novel standards for reporting and performance reflection. However, the absence of practical tools and control measures sets unique challenges for modern companies regarding efficient information delivery and goals fulfillment and requires more thorough research and analysis. Electricity generation sphere is not exceptional, as it covers quite an important social matter of affordable, clean energy and ecological impact. Therefore, various nonfinancial projects and incentives are becoming even more essential in terms of corporate policy and annual reporting.

Aim of study. To describe and analyze the key aspects of corporate non-financial reporting in terms of sustainable development as well as outline some crucial opportunities and challenges applicable to major electricity generation companies in Ukraine.

Methodology. This work was performed within an extensive methodological framework. Secondary data analysis which is mainly based on the evaluation of qualitative data ranges was used as a main research method. In the evolutionary perspective we studied the most recent years following the most essential indicators and performance information revealed in annual reports of leading companies. Shifting our research focus from financial to non-financial benefits, the main Ukrainian energy generation companies were comprehensively examined by means of comparative descriptive research design.

The full scope of both internal particularities and external circumstances was outlined using the systemic analytical approach. Complex corporate data analysis and extensive energy market study were held in order to define the key features of social and ecological policies under sustainability program fulfillment. Deduction and synthesis were used to generalize the practical outcomes of the conducted study and propose the modern ways on performance efficiency improvement in terms of sustainable development of both electricity generation companies.

Study results. Sustainability is the main driving force of modern companies all around the world. The key prerequisites are directly set by changes in both business environment and social life. The non-financial aspect is becoming even more crucial in scope of final reporting and measuring the outcomes of various ecological and social initiatives held by corporation. Corporate performance is mainly assessed based on economic efficiency and stakeholder value, although transparency and clear advantages of broad communication regarding human rights and responsible policies are equally significant. Indeed, nonfinancial reporting is the main tool for fulfilling corporate social responsibility with complex and conscious integration of economic, social and ecological aspects.

The most essential topics which are under discussion by both business and government in many countries are the following:

- human rights (establish corporate standards to defend human dignity and nullify discrimination);

- labor relations (voluntary employment and decent working conditions); 
- environmental initiative (local policies with huge global impact, ecological monitoring, protection and prevention);

- access to justice and fair treatment (rule of law, access to legal aid, user-friendly legislation);

- social dialogue and minority issues (improving communication with less socially secure groups and finding solutions for reaching equality and high awareness);

- anti-corruption measures.

There are also some undoubtedly important factors to take into account while managing sustainability issues in energy generation sphere in sense of national reflection of key development priorities (Fig.1).

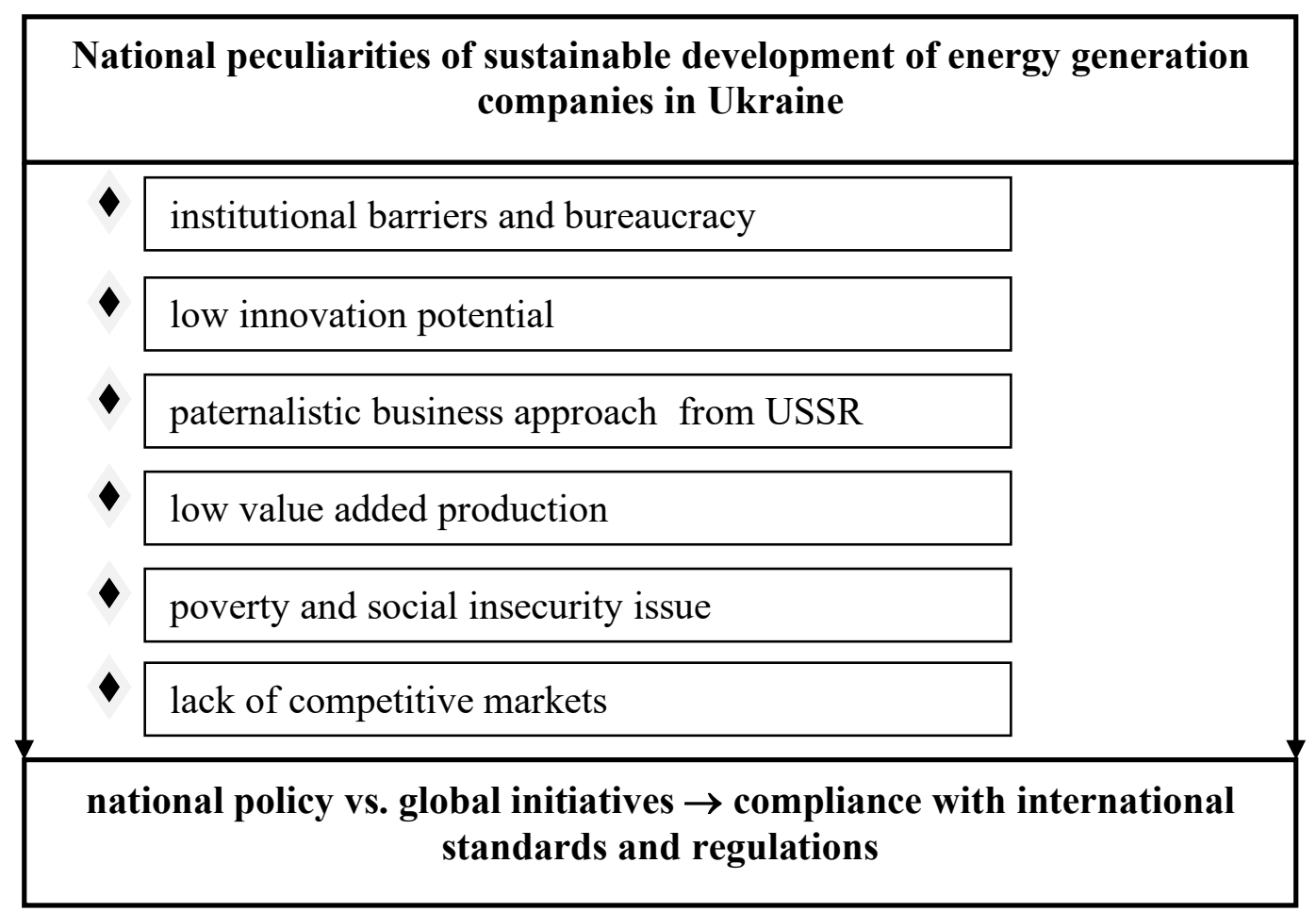

Figure 1. National peculiarities of sustainable development of electricity generation companies in Ukraine

Source: own compilation.

Energoatom is a company that operates four nuclear power plants with 15 power units with total installed capacity of 13,835 MW, 2 hydraulic units of Tashlyk PSP with installed capacity of $302 \mathrm{MW}$, and 2 hydraulic units of Oleksandrivka HPP with installed capacity of $11.5 \mathrm{MW}$. It provides about more than a half of Ukraine's need for electricity, during autumn-winter periods this figure reaches $70 \%$.

DTEK is the largest energy holding company in Ukraine managing four operating companies with assets in coal production, electricity generation and distribution, alternative energy and gas production. DTEK Energo is a key player in Ukraine's thermal generation and coal production. The company produces $2 / 3$ of coal and generates a quarter of the country's electricity.

Companies have different methods of generating electricity. Unfortunately, neither NPPs nor TPPs are harmless in terms of environmental impact. Nuclear power plants 
provide cheap electricity and are relatively environmentally friendly in terms of $\mathrm{CO} 2$ emissions, but they are very dangerous and risky, since it is proved more than one case of man-made disasters caused by nuclear power plant accidents - the Chornobyl disaster (1986), Fukushima Daiichi nuclear disaster (2011) etc. At the same time, TPPs create many environmental problems due to the emission into the atmosphere of a large number of gas and aerosol emissions, pollution of groundwater, and destruction of landscapes through coal production. However, these are not the problems of the businesses themselves. This is the matter of the lack of real alternatives to energy generation, which will continuously meet the demand of the population in electricity. Therefore, people are to look for new methods of generating energy, and the main task of existing energy companies is to minimize their intrusive and potential negative impacts and Energoatom with DTEK do so.

Both Energoatom and DTEK used to publish non-financial reports in accordance with international Global Reporting Initiative (GRI) standards. Nowadays GRI is the most widely used sustainability reporting format in the world. These standards offer a list of specific indicators for reporting on the social, environmental and economic activities of the enterprise. Using these standards and publishing non-financial reports is a signal that companies are concerned about their sustainable development, their environmental, social and economic responsibility to society.

These non-financial reports have a separate chapter about sustainable development of the company where they presents their contribution to the sustainable development (SD) of society, taking into account all economic, social and environmental aspects. Below we examine the reports of both companies and compare their approaches to formation.

Energoatom's non-financial statement is a separate, in-depth and comprehensive report. It includes the following main chapters: Responsible Governance, Sustainable Development, Effective investment, Safety Culture, Clean Environment, Employees and Communities and Annexes that include many important indicators. This deep approach enables the investor or any other interested person to evaluate the company's work towards sustainable development. At the same time, the non-financial report of DTEK is only part of the Integrated report and provides much less information on the company's sustainable development activities. The entire integrated report includes the following chapters: DTEK Group at a glance, Review of industries and Ukraine's macroeconomic indicators, Operating Performance, Corporate governance, Sustainability and Annexes. Following this information, only one chapter is completely dedicated to the sustainable development of the company. It includes data about environmental protection, society and employees. Also Annexes reveals many important indicators about the sustainable development of the company.

The UN Sustainable Development Goals have been integrated into DTEK Group's business strategy. 17 goals were set by world leaders at the UN General Assembly and officially took legal effect on January 1,2016. These goals set out a timeframe of 15 years, in which countries and organizations would focus on overcoming poverty, tackling inequality and eliminating the negative effects of climate change. Table 1 demonstrates 
the comparative analysis of UN Sustainable Development Goals in terms of our research objects.

\section{Table 1}

UN Sustainable Development Goals: Energoatom and DTEK focus

\begin{tabular}{|c|l|c|c|}
\hline № & UN Sustainable Development Goals & Energoatom & DTEK \\
\hline 1. & No poverty & + & - \\
\hline 2. & Zero hunger & - & - \\
\hline 3. & Good health and well-being & + & + \\
\hline 4. & Quality education & + & + \\
\hline 5. & Gender Quality & + & + \\
\hline 6. & Clean water and sanitation & + & + \\
\hline 7. & Affordable and clean energy & + & + \\
\hline 8. & Decent work and economic growth & + & + \\
\hline 9. & Industry, innovation and infrastructure & + & + \\
\hline 10. & Reduced inequality & + & - \\
\hline 11. & Sustainable cities and communities & + & + \\
\hline 12. & Responsible consumption and production & - & + \\
\hline 13. & Climate action & + & + \\
\hline 14. & Life below water & - & - \\
\hline 15. & Life on land & + & + \\
\hline 16. & Peace, justice and strong institution & + \\
\hline 17. & Partnerships for the goals & + & + \\
\hline
\end{tabular}

Source: own compilation based on [6-10].

The table shows that companies are working towards most UN Sustainable Development Goals, but there are some differences between them. So Energoatom does not focus on such goals as Zero hunger, Responsible consumption and production, Life below water, while DTEK adds to these goals No poverty, Reduced inequality, Peace, justice and strong institution, though focuses on Responsible consumption and production.

Energoatom pays competitive salaries to its employees and provides the necessary social benefits. The Company remains one of the largest taxpayers. In 2018, it ranked 2nd in the Top 10 biggest taxpayers in the energy sector, having paid UAH 10.69 billion in taxes. At the same time, DTEK paid more than $\$ 20$ billion in taxes.

Employees of Energoatom and DTEK receive social benefits in accordance with Ukrainian laws. These social benefits include various types of material assistance, healthcare services for employees, provision of accommodation (to the extent possible), as well as educational programmes. In 2018 14,760 employees of Energoatom had an 
opportunity to take advantage of health resort treatment and improve their health that worth UAH 156.8 million in total for the company. It also cares about the children of its employees. In 2018, Energoatom spent UAH 40.4 million on the rest and recreation of 5,644 children.

DTEK also provides an opportunity of health improvement of employees and their families at recreation centers of companies and health centers of DTEK Service used by 8,601 people. DTEK has 33 own health centers, 546 medical professionals, of which 77 are doctors and 16 psychologists that in 2018 provide 24,800 psychology consultations. This is extremely important, because psychological health is the key to motivation, discipline and productivity.

Also companies spend a lot on occupational safety of their employees. Figure 2 demonstrates the comparative cost analysis of both companies for occupational safety per employee.

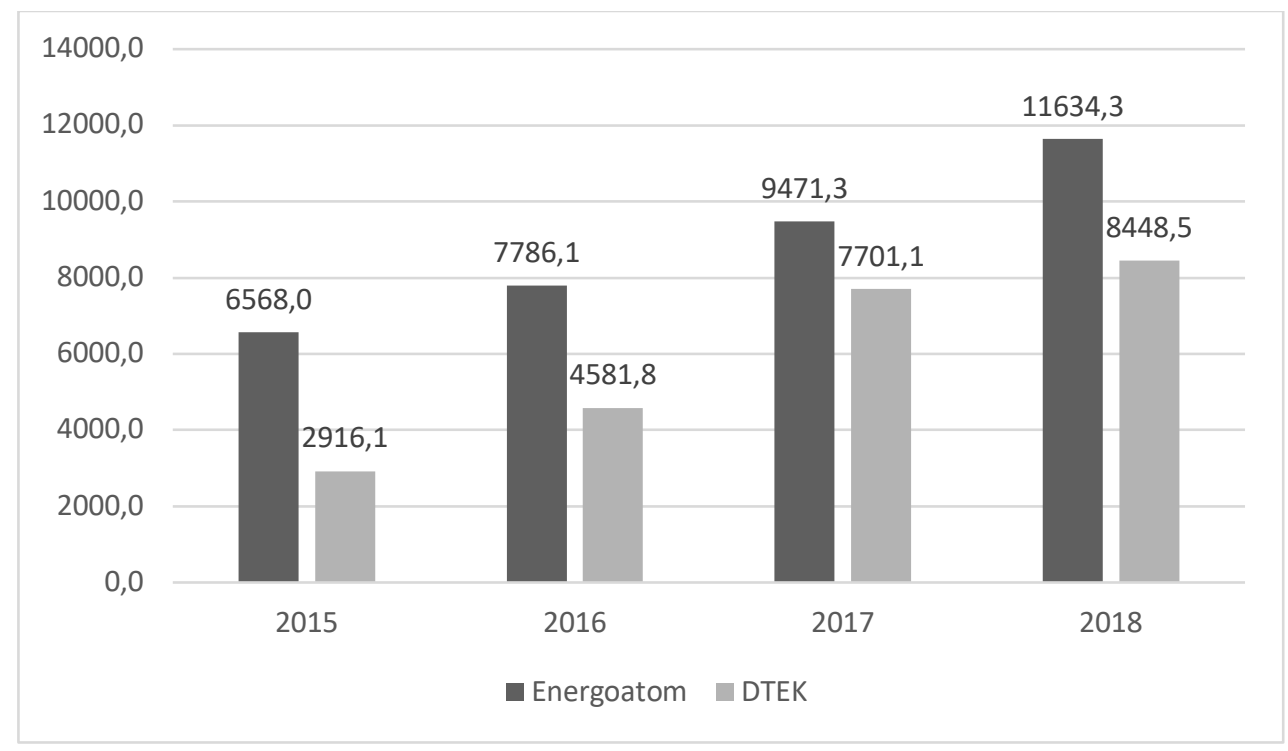

Figure 2. Dynamics of companies' occupational safety costs per employee, 20152018, UAH

Source: own compilation based on [6-10].

Following the Figure 2 data, Energoatom spends more money on the protection of its employees than DTEK, while the Energoatom has an average of 5.5 accidents, of which 0 are fatal, and DTEK has an average of 313 accidents, of which 8 are fatal. These are horrendous figures for DTEK, so they must increase costs for occupational safety for their employees.

Both companies pay considerable attention to enabling environment for training, professional development, and career development of employees at different levels (Figure 3). 


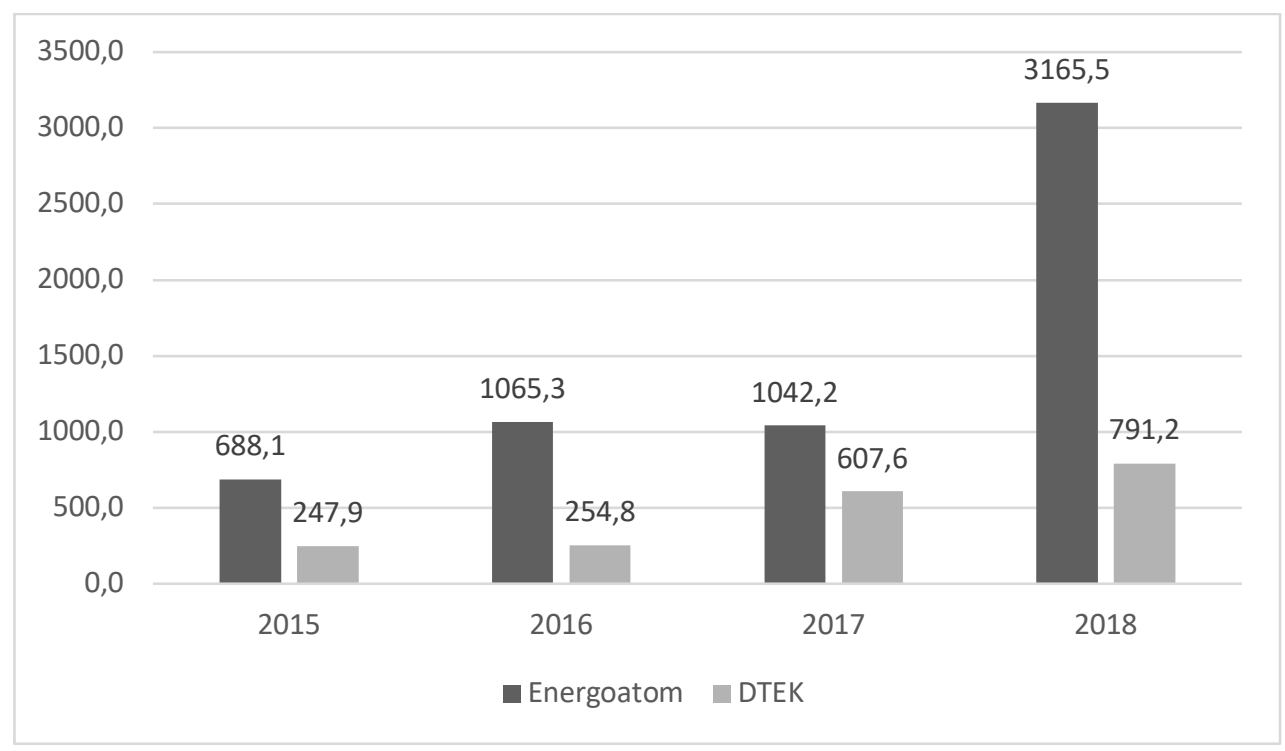

Figure 3. Dynamics of companies' staff training costs per employee, 2015-2018, UAH Source: own compilation based on [6-10].

Figure 3 shows that Energoatom spends a lot more money on employees education, which is a consequence of the different required level of training to work at different types of power plants. Nuclear power plants require more qualifications, practical laboratory tests, etc., because the very process of generating electricity at a nuclear power plant is much more complicated and dangerous. Also in 2018 Energoatom launched the Training Centre Building $G$ at Zaporizhzhya NPP that helps in training and upskilling repair and operation personnel in a simulated environment of the power unit operation. It makes personnel more qualified and therefore NPPs more safe.

Both companies focuses its water resource management efforts on economic and efficient use at all its production facilities. To ensure optimum water consumption, DTEK enterprises use both circulating water supply systems and reuse of water. In 2018, the company's power plants implemented the following activities aimed at more rational use of water resources and water treatment: DTEK Prydniprovs'ka TPP retro-fitted an automated system for monitoring and recording water supply and sanitation, by installing 32 instrument sets for measuring water flow at supply, distribution and drain nodes; DTEK Burshtyns'ka TPP reconstructed a drinking water pipeline, which ensured drinking water savings of 10 ths cubic meters per month; DTEK Dobrotvirs'ka TPP completed the first start-up complex of its project to reconstruct the water deferrification station. Now, treated wastewater is subject to iron removal of drinking water from wells, and then is reused to clean the filters. The project makes it possible to reduce discharges to local bodies of water by $95 \%$. Energoatom continues rolling out a project to complete Tashlyk Hydroelectric Pumped Storage Power Plant (hydropower units No. 3-6) with a gradual increase of Olexandrivske Reservoir on the Southern Buh River to the full reservoir level of $+20.7 \mathrm{~m}$ and an increase in the useful capacity to 72.6 million $\mathrm{m} 3$. This project is supposed to meet water supply needs of Mykolaiv Oblast. 
Both Energoatom and DTEK are developing the renewable energy sector. In DTEK it is led by DTEK Renewables. The company is actively building green power plants, and the amount of produced green energy should reach 1,000 MW in 2020. This also means that CO2 emissions will decrease by 2,650 tonnes per year.

Innovations in this industry are very important. They increase the energy security of the country, the efficiency of electricity generation, reduce electricity losses and the negative impacts on the environment.

Energoatom implements many projects that are important for the development of infrastructure and the industry as a whole. Here are some of them: constructing the Central Spent Fuel Storage Facility (CSFSF) in the Chernobyl Exclusion Zone to store spent fuel from the Ukrainian NPPs operating VVER reactors, building an Ukraine-EU Energy Bridge to integrate United Energy Systems of Ukraine with the European grid, completing power units No.3 and No.4 at Khmelnytska NPP, building complex lines for radioactive waste treatment.

DTEK's main goals in the area of industry development are the reduction of the share of imported energy resources in the country's fuel balance and integration with the European energy system ENTSO-E to strengthen the energy security of Ukraine. Here are some projects of DTEK's projects: DTEK Prydniprovs'ka TPP, DTEK Myronivs'ka CHPP were switched from anthracite to G-grade coal, DTEK Burshtyns'ka TPP has reconstructed power unit No.10. that increased capacity of the power unit by $15 \mathrm{MW}$ to $210 \mathrm{MW}$ and the service life of the equipment has been extended by 15 years, DTEK Zaporiz'ka TPP completed a pilot project to develop a standard plan for monitoring, reporting and verifying greenhouse gas emissions by thermal generation enterprises and 11 power units of DTEK Energy TPPs completed the reconstruction of automatic frequency and power control systems, which will ensure the maintenance of the current frequency in accordance with ENTSO-E standards.

Both companies set goals to reduce the negative impact on the environment. Under normal conditions, the operation of nuclear power plants has a smaller negative impact on the environment, but there is always the issue of their safety and disposal of radioactive waste. TPPs have a huge negative impact on the environment, as electricity is generated through the combustion process of exhaustive raw materials, which causes huge emissions of harmful substances into the atmosphere. Companies must offset their negative impact by paying environmental taxes. Figure 4 demonstrates the amount of companies`environmental taxes paid in the period of 2015-2018. 


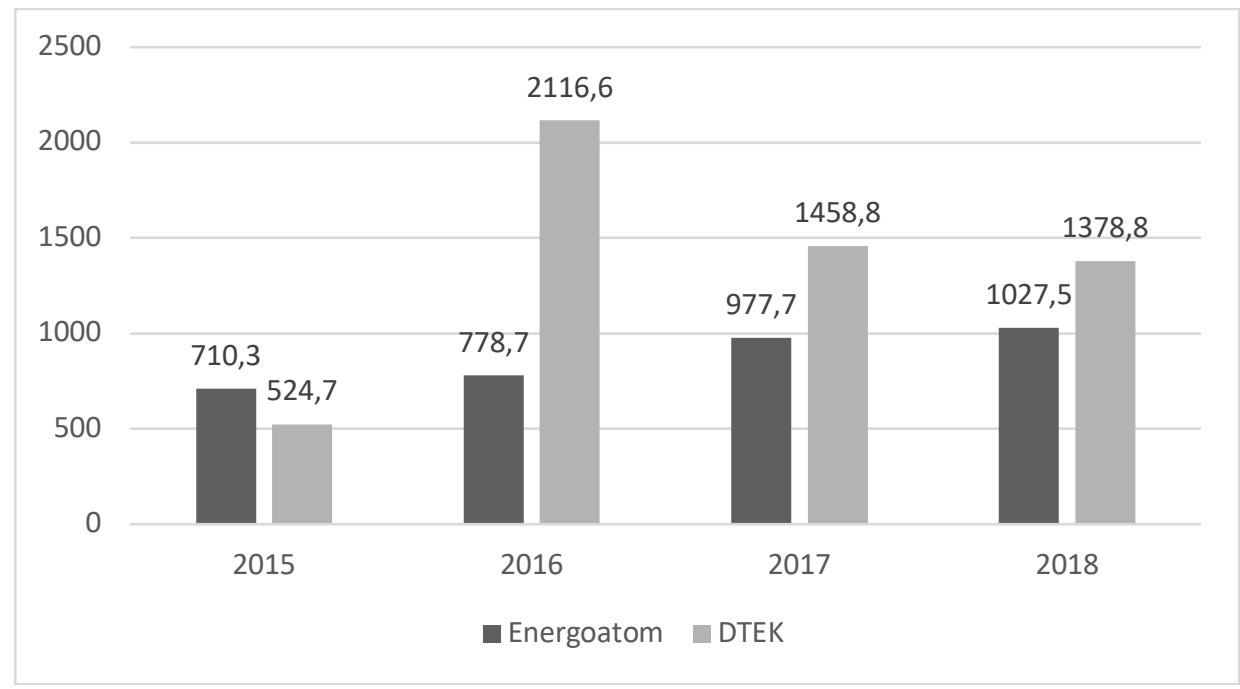

Figure 4. Dynamics of companies' environmental taxes, 2015-2018, million UAH Source: own compilation based on [6-10].

Following the data, companies pay large amounts of environmental tax each year. $45 \%$ of the collected tax is directed to the state budget, and $55 \%$ to the special fund of local budgets, which in the future can only be used to financially support the implementation of environmental measures. DTEK is a larger environmental taxpayer than Energoatom, due to its greater negative environmental impact. $45 \%$ of the collected tax is directed to the state budget, and $55 \%$ to the special fund of local budgets, which in the future can only be used to financially support the implementation of environmental measures.

But in addition to the environmental tax, companies also have other environmental expenses, financing projects and activities that reduce the environmental impact. Figure 5 indicates the amount of other environmental expenses of companies in the period of 20152018.

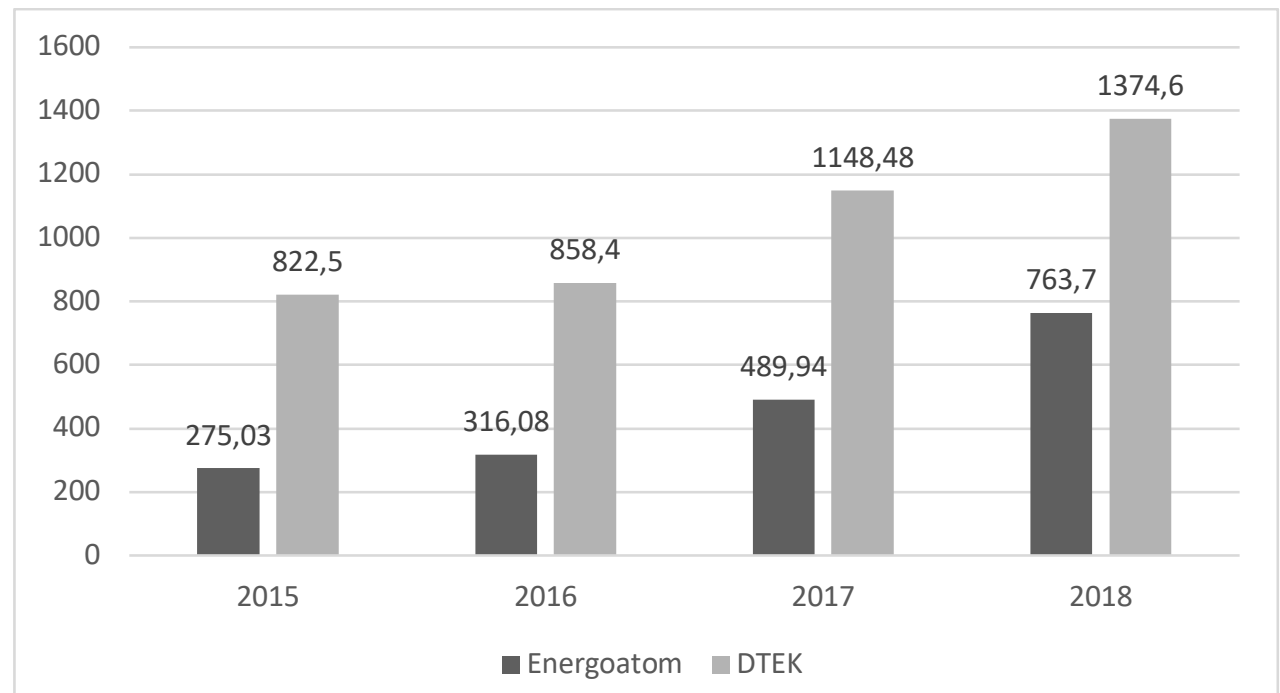

Figure 5. Dynamics of other companies' environmental expenses, 2015-2018, million UAH

Source: own compilation based on [6-10]. 
The environmental costs of both companies are increasing. DTEK spends more on environmental measures. DTEK spent 3 times more than Energoatom in 2015, but nowadays it is only 1.8 times more, meaning that Energoatom increases its environmental spending.

The companies adheres to the principles of European environmental laws and applies international standards and EU directives in the area of environmental protection. Here are some of the environmental projects that are implementing by our companies. Energoatom completed the first stage of tests of HI-TRAC transfer casks manufactured by Holtec International for spent fuel transfer and transportation. Energoatom also has the Complex (Consolidated) Safety Upgrade Programme of Power Units of Ukrainian NPPs in place that is designed until 2020. In 2018 it also commissioned complex lines for radioactive waste treatment at Rivne NPP and Zaporizhzhya NPP. DTEK Prydniprovs'ka TPP started using an automatic monitoring station for atmospheric air at the border of its sanitary protection zone. Programs for increasing the use of fly ash, slag and ASM have been developed and are being implemented at all TPPs of DTEK Energy. In 2018 the Pavlohrads'ka, Ternivs'ka, Blagodatna and Samarska mines on the area of 13 hectares planted trees.

Study Results. All things considered, it is highly important to emphasize the most important strategic points regarding sustainable development and integrated reporting performance of leading electricity generation companies in Ukraine - DTEK and Energoatom:

- define major risks as well as opportunities based on global shifts in electricity generation and transition spheres;

- identify key sustainable development goals and prioritize less visible outcomes in terms of less sector-driven ones;

- fulfill general international commitments regarding global requirements and industrial peculiarities;

- transform the industry in a quality manner following social and ecological imperatives as well as economic targets;

- lead the broad trend of transparent and responsible business, open to novel customer demands and high efficiency standards.

\section{References}

1. Kukharuk, A.D. \& D.D. Zmitrovych D.D. (2015) Formation of competitive advantages of enterprise considering sustainable development concept. Bulletin of the Kherson National Technical University. 15/2. pp. 46-48.

2. Khalatov, A.A. (2016) Energy sector of Ukraine: modern state and nearest prospects. Herald of National Academy of Sciences of Ukraine. 6. pp. 53-61.

3. Vasylchuk I.P. (2015) Sustainability reporting as a management tool for achieving of sustainable development in corporations. International Humanitarian University Herald. Economics and Management. 11. pp. 212-215.

4. Owusu, P.A. \& S. Asumadu-Sarkodie (2016) A review of renewable energy sources, sustainability issues and climate change mitigation. Cogent Engineering. [online]. Available at: https://researchmanagement.mq.edu.au/ws/portalfiles/portal/90104951/Publisher_version.pdf [Accessed 01 Nov. 2019].

5. Urban, F., \& T. Mitchell (2011) Climate change, disasters and electricity generation. [online]. Available at: https://opendocs.ids.ac.uk/opendocs/bitstream/handle/20.500.12413/2504/ 
Climate\%20Change\%2c\%20Disasters\%20and\%20Electricity\%20Generation.pdf?sequence=1\&isAllowe $\mathrm{d}=\mathrm{y}$ [Accessed 01 Nov. 2019].

6. Energoatom Non-Financial Report 2018. [online]. Available at: http://nfr2018.energoatom.kiev.ua/download/nfr_EA_2018_ENG.pdf
7. DTEK
Integrated
Report
2015.
[online].
Available at:

https://dtek.com/content/files/godovie_otchety_en/dtek-report-eng-2015-web.pdf

8. DTEK Integrated Report 2016. [online]. Available at: https://dtek.com/content/files/dtek_ar_2016_en_e-version.pdf

9. DTEK Integrated Report 2017. [online]. Available at: https://dtek.com/content/files/111dtek_ar_2017_eng.pdf

10. DTEK Integrated Report 2018. [online]. Available at: https://dtek.com/en/annual-report.

Кузнецова Марія, асистент кафедри економіки підприємства,

КНУ імені Тараса Шевченка

Пономаренко Сергій, магістр

КНУ імені Тараса Шевченка

\section{СТАЛИЙ РОЗВИТОК НАЙБЛЛЬШИХ ЕЛЕКТРОГЕНЕРУЮЧИХ КОМПАНІЙ В УКРАЇНІ: НЕФІНАНСОВІ АСПЕКТИ}

Стаття присвячена дослідженню питань сталого розвитку та інтегрованої звітності відповідно до найбільш сучасних рекомендацій для генеруючих компаній в Україні. В ході дослідження були виявлені ключові особливості діяльності провідних електрогенеруючих компаній в контексті відповідності міжнародним вимогам і глобальним викликам. Було розкрито основні фрактори перспективного розвитку українського енергетичного сектора з метою визначення можливостей для майбутнього зростання і структурних зрушень.

Теоретична і практична бази дослідження були наведені згідно 3 встановленими стандартами і принципами, а також механізмами управління ефективністю бізнесу і випуску інтегрованої звітності. Найбільш суттєві особливості різних типів виробництва електроенергії були визначені в рамках національних галузевих передумов. На основі даних, представлених в річних корпоративних звітах, а також статистичних даних був проведений порівняльний аналіз різних нефрінансових ініціатив і проектів корпоративної соціальної відповідальності 3 метою виявлення найбільш важливих відмінностей в наданні інформації про результати діяльності та їх поліпшенні. Значення соціальних і екологічних програм було доведено з точки зору сталого розвитку та забезпечення високої ефективності з урахуванням як внутрішніх, так і зовнішніх функціональних аспектів.

Ключові слова: управління ефективністю бізнесу, корпоративна соціальна відповідальність, генерація електроенергії, інтегрована звітність, сталий розвиток, сталість.

Кузнецова Мария, ассистент кафедры экономики предприятия,

КНУ имени Тараса Шевченко

Пономаренко Сергей, магистр

КНУ имени Тараса Шевченко 


\section{УСТОЙЧИВОЕ РАЗВИТИЕ КРУПНЫХ ЭЛЕКТРОГЕНЕРИРУЮЩИХ КОМПАНИЙ В УКРАИНЕ:}

НЕФИНАНСОВЫЕ АСПЕКТЫ

Статья посвящена вопросам устойчивого развития и интегрированной отчетности в соответствии с самыми последними рекомендациями для генерирующих компаний в Украине. В ходе исследования были выявлены ключевые особенности деятельности ведущих электрогенерирующих компаний в контексте соответствия международным требованиям и глобальным вызовам. Были раскрыты основные фракторы перспективного развития украинского энергетического сектора с целью определения возможностей для будущего роста и структурных сдвигов.

Теоретическая и практическая базы исследования были указаны в соответствии с установленными стандартами и широко распространенными принципами, а также механизмами управления эфрфективностью бизнеса и выпуска интегрированной отчетности. Наиболее существенные особенности различных типов выработки электроэнергии были определены в рамках национальных отраслевых предпосылок. На основе данных, представленных в годовых корпоративных отчетах, а также статистических данных был проведен сравнительный анализ различных нефинансовых инициатив и проектов корпоративной социальной ответственности с целью выявить наиболее важные различия в предоставлении информации о результатах деятельности и их улучшении. Значение социальных $и$ экологических программ было доказано с точки зрения устойчивого развития и обеспечения высокой эффрективности с учетом как внутренних, так и внешних функциональных аспектов.

Ключевые слова: управление эффрективностью бизнеса, корпоративная социальная ответственность, генерация электроэнергии, интегрированная отчетность, устойчивое развитие, устойчивость. 